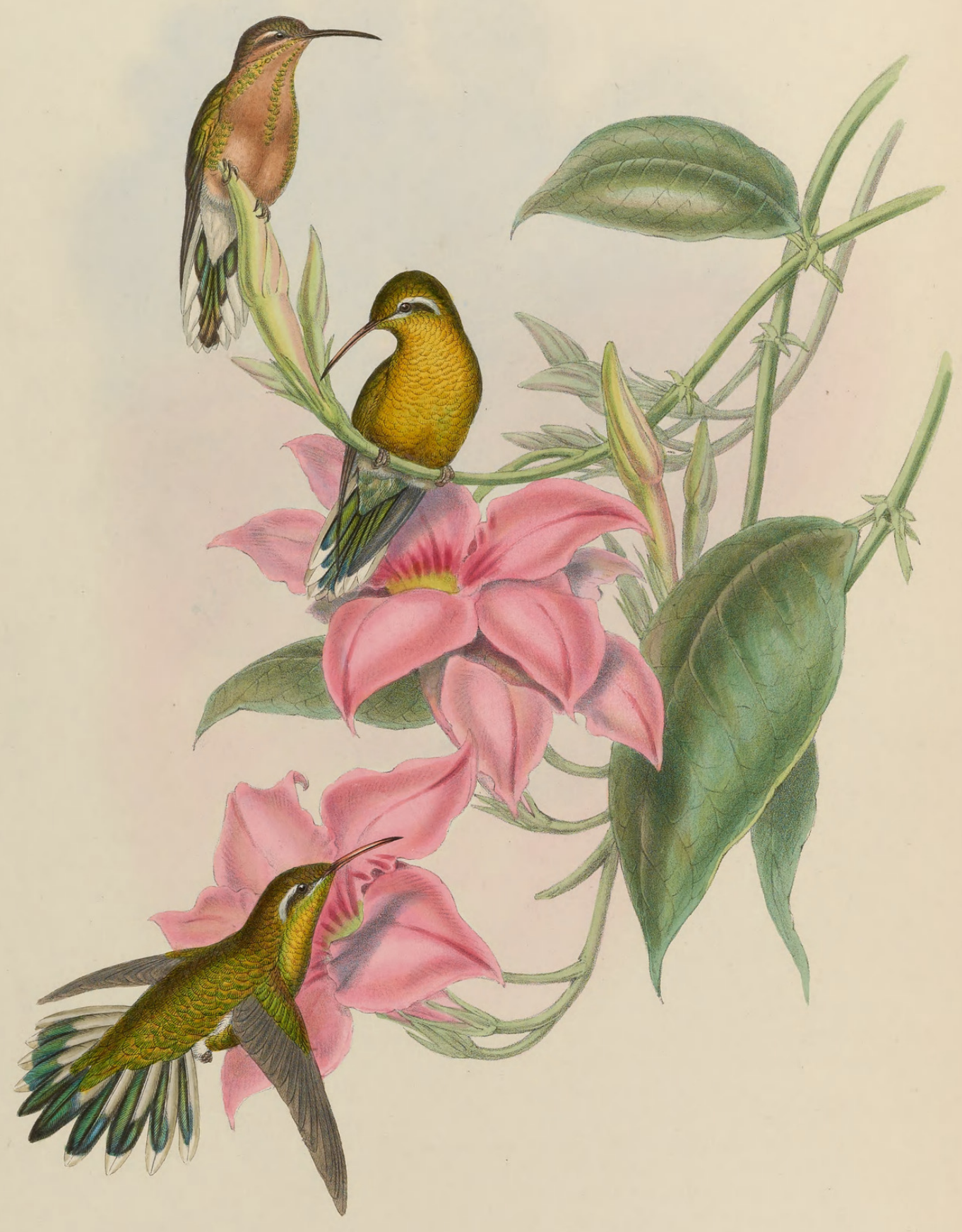




\section{CHRYSOBRONCHUS VIRESCENS.}

\section{Golden-throated Humming-bird.}

Trochilus Thaumantias, Linn. Syst. Nat., tom. i. p. 489.-Lath. Ind. Orn., vol. i. p. 309.Vieill. Nouv. Dict. d'Hist. Nat., tom. vii. p. 253

viridescens, Linn. Syst. Nat., Ed. 6., gen. 76. sp. 2.

Le Petit Colibri, Briss. Orn., tom. ii. p. 667. 2nd part.-Buff. Pl. Enl. 600. fig. 1.—Ib. Hist. Nat. des Ois., tom. vi. p. 64. sp. 19.

L'Oiseau-mouche à queue verte et blanche, Aud. et Vieill. Ois. Dor., tom. i. p. 83. pl. 41.

Admirable Humming-bird, Lath. Gen. Syn., vol. ii. p. 763. no. 25.-Ib. Gen. Hist., vol. iv. p. 318. sp. 39.—Shaw, Gen. Zool., vol. viii. p. 285.

Bright-throated Humming-bird, Lath. Gen. Hist., vol. iv. p. 309. no. 28.—Shaw, Gen. Zool., vol. viii. p. 287.

Trochilus virescens, Dumont, Dict. Sci. Nat., 1818.-Licht. Cat.-Vieill. Nouv. Dict. d'Hist. Nat., tom. xxiii. p. 428.-Prince Max, Beit. zur Naturg. von Bras., p. $10 \%$. chrysobronchus, Shaw, Gen. Zool., vol. viii. p. 287._-Ib. Steph. Cont., vol. xiv. p. 240. viridis, Vieill. Nouv. Dict. d'Hist. Nat., tom. vii. p. 354.

Ornismya viridis, Less. Hist. Nat. des Ois.-mou., p. 178. pl. 60.-Ib. Les Troch., p. 144. pl. 54. Trochilus chloroleucurus, Saucerotte.

Polytmus chrysobronchus, Gray and Mitch. Gen. of Birds, vol. i. p. 108, Polytmus, sp. 52.

Chrysobronchus virescens, Bonap. Rev. et Mag. de Zool. 1854, p. 252.

Leucippus chrysobronchus, Reichenb. Aufz. der Colibris, p. 11.

THE adult plumage of the bird figured on the accompanying Plate is so resplendently beautiful that it defies all the powers of art to give its faithful portraiture; I must therefore content myself with as close a representation of it as possible. Its native country is Brazil, over which it ranges from Rio de Janeiro to the Amazon, and thence probably throughout the whole of the seaboard to the Isthmus of Panama, as I have specimens collected on the Magdalena by M. Warszewicz. It is also found in Trinidad. The individuals from the latter locality are, however, somewhat smaller in size and have more white on their tail-feathers than those found in Brazil, and I have often thought these differences might be of sufficient importance to constitute a distinct species.

The synonymy of the Chrysobronchus virescens, like that of some other members of the family, is in a sad state of confusion; on this point I have consulted with the celebrated French Trochilidist, M. Bourcier of Paris, and the above list is given on his authority.

The specimens sent to this country usually arriving unlabelled, we have no means of determining if there be any marked difference in the colouring of the sexes ; so far as may be judged from an examination of a large number of specimens, they are similar; on the other hand, the young have a very different style of colouring, as may be seen on reference to the accompanying Plate, where a specimen is figured in a state of change from youth to maturity. I have a young specimen in my collection, which, it is pretty certain, was sent from Bogota; but if this be the case, the bird must be regarded as rare in that district.

All the upper surface, wing- and tail-coverts golden green; throat, chest and abdomen light luminous golden green; wings purplish brown; tail shining green; the lateral feathers with a stripe of greyish white along the basal portion of the outer web and tipped with greyish white; under tail-coverts green; vent white.

In the young the under surface is deep fawn colour, with a line of golden-green feathers down the centre of the throat, and the white portion of the tail is very conspicuous.

The Plate represents adults and young of the natural size. The plant is the Dipladenia acuminata. 


\section{$2 \mathrm{BHL}$ Biodiversity Heritage Library}

Gould, John. 1858. "Chrysobronchus virescens, Golden-throated Humming-bird. [PI. 230]." A monograph of the Trochilidae, or family of humming-birds 4, https://doi.org/10.5962/p.317039.

View This Item Online: https://www.biodiversitylibrary.org/item/108334

DOI: https://doi.org/10.5962/p.317039

Permalink: https://www.biodiversitylibrary.org/partpdf/317039

\section{Holding Institution}

Smithsonian Libraries

\section{Sponsored by}

Smithsonian Institution Libraries

\section{Copyright \& Reuse}

Copyright Status: NOT_IN_COPYRIGHT

This document was created from content at the Biodiversity Heritage Library, the world's largest open access digital library for biodiversity literature and archives. Visit BHL at https://www.biodiversitylibrary.org. 